\title{
The Effects of IT management on empowering the bank employees in Tehran (Case Study: Employees of private banks in Tehran)
}

\begin{abstract}
Purpose: This study has been arried out in the first half of 2015aiming to examine the effects of informationtechnology management on empowering the Employees of private banks in Tehran.
\end{abstract}

Research Method: This study is descriptivesurvey which is an applied research in terms of objective. The population consisted of 40 employees of private banks in Tehran. Questionnaire was used to collect data whose reliability is $918 / 0$ based on Cronbach's alpha and its validity was also confirmed.

Findings: In this study, the factors associated with empowerment of employees' job including improved performance quality, increased responsibility for decision-making, increased job diversity, increased self-controlling, ability and desire, communication with organization, creativity, sponsorship and support were considered. The findings confirmed with 99.8 percent that application of information technology management will empower the employees.

Keywords: information technology, empowerment, management of private banks, Tehran

Introduction: Information Technology and use of computers, Internet and other electronic devices in the organizationhas caused rapid new precise information and knowledge, and also enhanced the abilities and capacities of the employee. In fact, IT has excluded the role of employee from their traditional form by

1- Islamic Azad University, North Tehran branch. Management faculty/post graduate department
The changes made in these processes. The role of employee has adopted a new form due to the provision of new services. In this regard, human resource is vital to successfully provide serviceoriented services. The application of information technology in all banks in every shape and size depends essentially on three factors: hardware, software and human resources.. IT enables managers to better communicate with organization, environment and each other. Participation in decision-making, speed up decision making, faster problem identification, shorter pyramid of organization, improved coordination and increased professional staff are just some of the effects that information technology management and information systems have on some of the organizations.

. (Stoner and Freeman, 1378, p. 86)

Empowerment is actually providing more freedom, job independence, responsibility for decision-making and self-control to do things for the employees of an organization. Strengthening organizational performance is possible through full use of the employee's knowledge, skills, experience and wisdom, it is believed that creativity and innovation is realized when the organization benefits from creative and motivated resources. Accordingly, empowerment of human resources means creating necessary capacities to enable them for added value with efficiency and effectiveness and the role they have to play in the organization. 
Proc. of the Fourth Intl. Conf. Advances in Social Science, Economics and Management Study- SEM 2016 Copyright (C) Institute of Research Engineers and Doctors, USA .All rights reserved.

ISBN: 978-1-63248-094-1 doi: 10.15224/ 978-1-63248-094-1-51

\section{Research method}

This research is descriptive-survey in nature and methods and also an applied research in terms of objective. Data collection was conducted through a researcher-made questionnaire.. Questionnaires were given to the employees of private banks in person. Data were analyzed by SPSS and Excel. Cronbach's alpha was equal to 0.918 indicating the reliability. And the validity was also confirmed.

\section{Findings}

Does information technology increase the ability of employees of private banks?

Based on the results obtained, 95\% of employees believe that the information technology provided in the organization has widely affected the ability of employees.

Does information technology increase the performance improvement of employees of private banks?

According to the results, $85 \%$ of people believe that information technology has widely improved their performance; it means that information technology has caused productivity and performance improvements among the employees.

Does information technology increase the further support of the organizational goals?

According to the results, $85 \%$ of people believe that information technology has mainly increased support of organizational goals; it means that meeting organizational pre-determined plans and goals depends on wider use of IT.

Does information technology increase the independence and freedom of the employees of private banks? Based on the results obtained from the samples, $77.5 \%$ of people stated that information technology has mainly increased the independence and freedom of the employees and only $2.5 \%$ of them considered the lower impact of information technology on increasing the independence and freedom.

Does information technology increase the responsibility of decision-making in the employees of private banks?

Based on the results, all employees of private banks believe that information technology plays a very important role in their decisions and using these tools and technologies has increased responsibility for decision-making in banking matters. Does information technology increase job diversity of the employees of private banks? Based on the results obtained from the samples, $75 \%$ of people stated that information technology is effective on the increased job diversity and creation; indicating that IT has developed job diversity and creativity in workplace of the employees. Does information technology increase the capacity and willingness of the employees?

Table1. Frequency distribution of the effect of information technology management on increasing the capacity and willingness of the employees

\begin{tabular}{|l|l|l|l|}
\hline & Frequency & $\begin{array}{l}\text { Frequency } \\
\text { in percent }\end{array}$ & $\begin{array}{l}\text { Frequency } \\
\text { accumulative } \\
\text { percent }\end{array}$ \\
\hline Very low & 0 & 0 & 0 \\
\hline Low & 1 & 2.5 & 2.5 \\
\hline Medium & 7 & 17.5 & 20 \\
\hline High & 22 & 55 & 75 \\
\hline Very high & 10 & 25 & 100 \\
\hline Total & 40 & 100 & \\
\hline
\end{tabular}


Proc. of the Fourth Intl. Conf. Advances in Social Science, Economics and Management Study- SEM 2016

Copyright (C) Institute of Research Engineers and Doctors, USA .All rights reserved.

ISBN: 978-1-63248-094-1 doi: 10.15224/ 978-1-63248-094-1-51

Based on the results, $80 \%$ of people has considered IT as a cause to increase capacity and willingness of the employees; indicating that IT widely increases the capacity of the employees in private banks to provide services to the clients which is together with the willingness and satisfaction of the employees.

Does information technology increase the communication, and creativity?

Table2. Frequency distribution of the effect of information technology management on increasing job diversity and creativity

\begin{tabular}{|l|l|l|l|}
\hline & Frequency & $\begin{array}{l}\text { Frequency } \\
\text { in percent }\end{array}$ & $\begin{array}{l}\text { Frequency } \\
\text { accumulative } \\
\text { percent }\end{array}$ \\
\hline Very low & 0 & 0 & 0 \\
\hline Low & 2 & 5 & 5 \\
\hline Medium & 8 & 20 & 25 \\
\hline High & 18 & 45 & 70 \\
\hline Very high & 12 & 30 & 100 \\
\hline Total & 40 & 100 & \\
\hline
\end{tabular}

Based on the results from Table 2, 75\% of people believe that information technology has mainly enhanced creativity, indicating that if the information technology is institutionalized in an organization and pervasively applied among the employees of private banks, it leads to creativity and prosperity.

Does information technology increase the self-control of the employees in private banks?

Table3. Frequency distribution of the effect of information technology management on increasing self-control

\begin{tabular}{|l|l|l|l|}
\hline & Frequency & $\begin{array}{l}\text { Frequency } \\
\text { in percent }\end{array}$ & $\begin{array}{l}\text { Frequency } \\
\text { accumulative } \\
\text { percent }\end{array}$ \\
\hline Very low & 0 & 0 & 0 \\
\hline Low & 1 & 2.5 & 2.5 \\
\hline Medium & 13 & 32.5 & 35 \\
\hline High & 17 & 42.5 & 77.5 \\
\hline Very high & 9 & 22.4 & 100 \\
\hline Total & 40 & 100 & \\
\hline
\end{tabular}

Based on the results from Table 3,64.9\% of people believe that IT increases self-control. The significant effect of IT on the prevention of mistakes and also automatic control of the employees' performance causes this tool to be widely used in managers' plans.

Does information technology increase the communication with organization?

Table4. Frequency distribution of the effect of information technology management on increasing communication with organization

\begin{tabular}{|l|l|l|l|}
\hline & Frequency & $\begin{array}{l}\text { Frequency } \\
\text { in percent }\end{array}$ & $\begin{array}{l}\text { Frequency } \\
\text { accumulative } \\
\text { percent }\end{array}$ \\
\hline Very low & 1 & 2.5 & 2.5 \\
\hline Low & 3 & 7.5 & 10 \\
\hline Medium & 6 & 15 & 25 \\
\hline High & 18 & 45 & 70 \\
\hline Very high & 12 & 30 & 100 \\
\hline Total & 40 & 100 & \\
\hline
\end{tabular}

Based on the results of Table 4, $75 \%$ of people stated that IT is effective on increasing communication with the organization. In other words, a significant majority of employees of private banks have

continues and extensive communication with the organization using IT. 
Proc. of the Fourth Intl. Conf. Advances in Social Science, Economics and Management Study- SEM 2016

Copyright (C) Institute of Research Engineers and Doctors, USA .All rights reserved.

ISBN: 978-1-63248-094-1 doi: 10.15224/ 978-1-63248-094-1-51

\section{Research hypotheses test:}

Hypothesis: The use of information technology causes to empower the employees of private banks.

. To this end we define the following two basic assumptions:

IT has no effect on the ability of private bank employees $=\mathrm{H} 0$

IT has effect on the ability of private bank employees $=\mathrm{H} 1$

Since standard deviation of the population is not known, we put SD of the sample instead. In such cases, we use another distribution close to normal, as the test statistic. The distribution is called $t$ distribution (t-test) and the value of the test statistic is calculated as follows:

$t=\frac{X-\mu}{S / \sqrt{n}}$

Because the sample size is 40 people, the random sample of 27 questionnaires was selected.

SPSS output for this sample is as follows:

One-Sample Statistics

\begin{tabular}{|c|l|}
\hline & $\begin{array}{l}\text { Empowerment } \\
\text { indicator }\end{array}$ \\
\hline $\mathrm{N}$ & 2 \\
\hline Mean & 95.074 \\
\hline Std. Deviation & 14.8346 \\
\hline Std. Error Mean & 2.8549 \\
\hline
\end{tabular}

\begin{tabular}{|c|c|c|}
\hline & \multicolumn{2}{|c|}{ Empowerment indicator } \\
\hline $\mathrm{T}$ & \multicolumn{2}{|l|}{3.529} \\
\hline $\mathrm{DF}$ & \multicolumn{2}{|l|}{26} \\
\hline Sig. (2-tailed) & \multicolumn{2}{|l|}{0.00} \\
\hline Mean Difference & \multicolumn{2}{|c|}{10.0740} \\
\hline \multirow{2}{*}{$\begin{array}{l}95 \% \text { confidence interval } \\
\text { Of the difference }\end{array}$} & Lower & 4.2057 \\
\hline & Upper & 15.9425 \\
\hline
\end{tabular}

According to the table above and a significant level of 0.002, the null hypothesis (IT has no effect on the empowerment of private bank employees) is rejected.

$\mathrm{P}=0 / 002<0 / 05$ Thus, as the above explanation shows, the probability of the effect of information technology on the empowerment of private banks' employees amounted to 99.8 percent.

It can be seen through t-test score that the $\mathrm{t}$-score for $\mathrm{DF}=26$ is equal to 2.056 . The above table shows that $\mathrm{t}=3.529$ and $\mathrm{t}=3.529>2.056$, therefore the null hypothesis is rejected.

\section{Discussion and conclusion}

In response to the first question of the basic questions it can be said that $95 \%$ of employees of private banks widely considered the effect of information technology management.

In response to other basic questions, it can be said respectively: $85 \%$ of people believe that information technology has widely improved their performance and increased the support of organizational goals;. $77.5 \%$ of people stated that information technology has mainly increased the independence and freedom of the employees.

On the other hand, all employees of private banks believe that information technology plays a very 
Proc. of the Fourth Intl. Conf. Advances in Social Science, Economics and Management Study- SEM 2016

Copyright (C) Institute of Research Engineers and Doctors, USA .All rights reserved.

ISBN: 978-1-63248-094-1 doi: 10.15224/ 978-1-63248-094-1-51

important role in their decisions and using these tools and technologies has increased responsibility for decision-making in banking matters. $75 \%$ of people stated that information technology is effective on the increased job diversity and creation; indicating that IT has developed job diversity and creativity in workplace of the employees. $80 \%$ of people has considered IT as a cause to increase capacity and willingness of the employees; indicating that IT widely increases the capacity of the employees in private banks to provide services to the clients which is together with the willingness and satisfaction of the employees.

$64.9 \%$ of people believe that IT increases selfcontrol. The significant effect of IT on the prevention of mistakes and also automatic control of the employees' performance causes this tool to be widely used in managers' plans. $75 \%$ of people stated that IT is effective on increasing communication with the organization. In other words, a significant majority of employees of private banks have continues and extensive communication with the organization using IT.

The findings in the hypotheses test section showed that the use of IT in empowering employees of private banks was approved by 99.8 percent.

\section{References:}

1. AtashZar, S. Peyman (2010). Evaluatingthe effectiveness of IT in enablingemployees of airports in the country. Thesis Master of Business management, Faculty of Social Sciences and Economic, PNU ofQeshm

2. AkhavanAlavi, SM (2009).investigation of information technology (IT) effect onempowers employees of treatment management of Social Security in Kashan. Master Thesis, Publicmanagement, University of Naragh.

3. Stoner, James and Edward Freeman (1996), management (translated by Mohammad Arabi), Tehran: the Institute of Business Studies publication.

4. SartipiYarAhmadi, Rosita (2008), application of information technology to empower employees in Library of Azad University of region 5, No. 5, Journal of Knowledge

5. ZiaeeKashani, Loa'abat (2005) the role of human resource empowerment in organizational effectiveness, (53), the journal of rubber industry

6. Malynkonyko, Michael, "information required by librarians in the age of technology", Translator Din Ahmad Lari, Quarterly notification, Volume 10, Number 4 Spring 1373

7. Mehrinejad, Safia, (2002) the use of information technology in political economic organizations, 181 and 182, takmonthly

8. . Haji Zeinolabedini, M. (2007).Security devices in libraries and information centers., articles collection of the Ninth International Conference on Management and Planning Library, Shiraz, April 21-23, (pp. 527-564).

9. BayatBodaghi, N; Farrokhi, Farhang (2010).Security and physical safety of the public and academic libraries in the Zanjan province. Book Quarterly, 84, 22-33. 